\title{
Hao Ran and the Cultural Revolution
}

\section{Citation}

Tian, Xiaofei. 2016. "Hao Ran and the Cultural Revolution." The Oxford Handbook of Modern Chinese Literatures (2016): 356-372.

\section{Published Version}

doi:10.1093/oxfordhb/9780199383313.013.18

\section{Permanent link}

http://nrs.harvard.edu/urn-3:HUL.InstRepos:34216391

\section{Terms of Use}

This article was downloaded from Harvard University's DASH repository, and is made available under the terms and conditions applicable to Open Access Policy Articles, as set forth at http:// nrs.harvard.edu/urn-3:HUL.InstRepos:dash.current.terms-of-use\#OAP

\section{Share Your Story}

The Harvard community has made this article openly available.

Please share how this access benefits you. Submit a story.

Accessibility 


\section{Hao Ran and the Cultural Revolution}

Xiaofei Tian

A godly thorough reformation,

Which always must be carried on,

And still be doing, never done....

-Samuel Butler (1613?-1680),

\section{Hudibras}

A young wife in bed: alone, sleepless, tormented by longing for her husband on a beautiful, if a little precious, moonlit night. This is a classic trope in the Chinese literary tradition, one of the most evocative motifs appearing in countless premodern poems and stories and possessing an immense cultural resonance. Then, in a story whose third, and final, version was written in "Beijing of the red month of May of 1957," we see just such a young bride lying in bed alone and experiencing "misery for the first time in her life." It turns out, however, that instead of being tortured by unfulfilled desire for her absent husband, she is thinking about her backward father-in-law. ${ }^{1}$ Fifteen years later, during the Chinese Revolution era, the author Hao Ran 浩然 (1932-2008), then already a famous writer, revealed that the real-life archetype for the heroine of his story was a girl who had had clashes with her parents; but feeling that a woman's conflict with her parents-in-law could become more "easily intensified and representative," he had changed "father and daughter" to "father-in-law and daughter-in-law."2 In the same essay, Hao Ran claims that his stories are not "written into being," but "revised into being." 
In many ways, the act of revision on the part of the paradigmatic [is this addition ok; I feel we need some explanation for the emphasis on the] socialist peasant writer Hao Ran-whether it is the problematic repackaging of a classic theme or the rewriting a text to make it more correct-presents an allegory of the central issue to be discussed in this chapter: cultural revolution..

\section{Cultural Revolution and the Treachery of the Literary Language}

In its narrow sense, the term cultural revolution refers to the Great Proletarian Cultural Revolution (1966-1976), a politically motivated mass movement that was launched by Chairman Mao Zedong. One of its essential purposes, as indicated by its name, was to revolutionize Chinese culture. If, however, we look beyond the term's immediate association, we find that cultural revolution is a recurrent theme in modern Chinese literary and social history; and, as scholars have suggested, the roots of the Great Proletariat Cultural Revolution must be examined "in the context of certain tendencies in Chinese cultural and social developments in the twentieth century." ${ }^{4}$ We could identify at least three important moments before the 1966 dateline that form an intellectually coherent narrative of the cultural revolution of modern China. The first two are obvious: the New Culture movement in the early twentieth century that advocated a break with the cultural past to mold a new, modern China, and then the year of 1942, when Mao delivered his famous talks at the Yan'an Forum on Literature and Arts from the Communist Party's headquarters in Yan'an, Shaanxi. ${ }^{5}$ In these talks, Mao formulated an ideological guideline for the development of literature and the arts in a socialist regime: they must serve the 
workers, the peasants, and the soldiers, and be subjected to the political interests of the Party. ${ }^{6}$

The third moment in the narrative of continuous cultural revolution in modern China, as a follow-up of the Yan'an talks, is less obvious but no less crucial than the first two. 1958 was the year of the Great Leap Forward, a socioeconomic campaign to vastly accelerate the nation's industrial and agricultural production. In a parallel move, Mao also launched a Great Leap Forward in cultural production that same year: poems-referred to as “folk songs" (min'ge 民歌)—were produced in massive quantity. Over 200,000 poems were reportedly composed in one shire by its 267 "poetry writing units." ${ }^{7}$ Written on posters, blackboards, walls, wooden or bamboo plaques, as well as orally composed in public poetry competitions, verses proliferated from city streets to farming fields. They were pared down and selected into a slim volume entitled Hongqi geyao (紅旗歌謠; Red Flag Ballads), edited by none other than the cultural luminaries of the People's Republic, Guo Moruo 郭沫若 (1892-1978) and Zhou Yang 周揚 (1908-1989). With its three hundred poems divided into four sections, respectively entitled "Odes to the Party" and "Agricultural, Industrial, and Military Songs," the anthology turns out to be a socialist recreation of the Classic of Poetry (Shi jing 詩經), China's earliest, and most canonical poetry collection that was supposedly pared down to about three hundred from three thousand poems and edited by Confucius himself. To further drive the parallel home, the editors in the preface of Red Flag Ballads explicitly refer to the anthology as "the new 'Airs of the Domains' [“Guofeng” 國風, the first section of the Shi jing] of the new socialist age." And yet, compared to the Red Flag Ballads, "even the Three Hundred Poems [a traditional reference 
to the Shi jing] are outshone." 8 The same year also saw the publication of Mao's nineteen poems in English translation by Beijing's Foreign Language Press; the number nineteen, like three hundred, bears a special significance because of the canonical group of poems traditionally referred to as the "Nineteen Old Poems," which, along with the Classic of Poetry, stands at the fountainhead of classical Chinese poetry. 1958 was a year of astronomical production figures and magic numbers.

The poems of the "Airs" section of the Classic of Poetry were supposed to have been popular songs sung by the common folk, serving as symptoms and signs of the people's moods. If the king gets to hear the distressed songs and is wise, he reforms the government. One legend about the origin of the "Airs" is that the Zhou kings sent officials to villages to collect songs in order to learn the people's concerns, an unmistakable antecedent for Red Flag Ballads. The immense cultural resonance again emerges in Chen Kaige’s 陳凱歌 1984 film, Yellow Earth (黃土地), which opens with a Communist soldier collecting local songs on the barren plateau of northern Shaanxi, the birthplace of the Communist revolution as well as the old Zhou heartland.

The poems of Red Flag Ballads, in glaring contrast to the "Airs" that mostly sing of a world gone wrong, are all joyful. With the people being so happy, there is no need for the government to reform, and the moral education implicit in this volume is directed at a different target altogether. In the words of its editors, Red Flag Ballads is intended to enlighten "our writers and poets" — the traditional scholar elite, known today as the "intelligentsia" - for "the new folk songs will produce a greater and greater influence on the development of modern poetry." 9 Mao was intent on transformation: the common folk into a self-conscious, progressive proletariat, and the intellectuals into humbled members of the 
laboring masses. Ironically, he chose to begin with "teaching through poetry," the ancient Confucian method of bringing about social change.

No writer embodies the transformed and transformative common folk better than Liang Jinguang 梁金廣 (1932-2008), better known as Hao Ran, the socialist writer laureate par excellence, whose fiction primarily focuses on rural life in north China in the socialist construction period. Publishing his first short story in 1956, Hao Ran is best known for his novels Bright Sunny Skies (艶陽天) and The Golden Road (金光大道): both sold millions of copies and were made into movies in the 1970s, turning Hao Ran into a household name and the most eminent writer during the Great Proletarian Cultural Revolution period. Growing up in rural poverty and orphaned at a young age, Hao Ran only received three and a half years of schooling, probably less formal education than any other prominent modern writer. He was not only saved from destitution by the Communist Party, but also owed his literary stardom entirely to opportunities created by the new socialist regime. ${ }^{10}$

An antithesis of the traditional Chinese cultural elite, Hao Ran epitomizes the cultural revolution of modern China because he wrote from within the peasants as a peasant himself, not the gentleman observer standing on the outside looking in. For centuries the Chinese elite had romanticized and glamorized farmers, extolling their freedom from the pressures of public life constraining a scholar-official, or sympathizing with their sufferings in hard times; but the farmers were always objects of a distant gaze and never talked back—until Hao Ran. Quite aware of his unique place in the Chinese literary tradition, Hao Ran justifiably refers to his story of success as a "miracle," and to himself as "a representative of the peasants marching toward culture."11 
A product of Mao's cultural revolution and its living embodiment, Hao Ran the peasant writer carried on the revolution by, to use an old Chinese metaphor, "tilling with his pen" (筆耕). His writings exemplify the complex modes of meaning production in China's socialist literature, which is frequently described as no more than revolutionary propaganda serving the state ideology. Socialist literature, especially from the early years of the People's Republic, is essentially performative: instead of being merely representational or reflective of a pre-existing "socialist reality," it attempts to found a new social order by proclaiming it, and is thus constitutive of the socialist reality. And yet, as J. Hillis Miller put it, "[all] performatives are to some degree out of the control of the one who speaks them."12 The creative participation of readers figures prominently in meaning production. In her book on Cultural Revolution culture, Barbara Mittler stresses the diverse interpretations to which Cultural Revolution propaganda art has been subjected by the Chinese people. Pointing out that "Cultural Revolution (and perhaps all) propaganda was received and experienced in many different, and often contradictory, ways by individuals from different generations and backgrounds," she rightly balances the agency of artists with that of audiences. ${ }^{13}$

While the author's intention and the reader's interpretation can and do frequently clash with each other, the text itself may also prove protean and uncontainable. This chapter wishes to call attention to a particularly intriguing aspect of socialist verbal art: the treacherous working of literary language. The socialist writer may yearn for newness in terms of literary expressions and moral values; but just as Mao employed the old Confucian program to achieve his cultural revolution, the very medium used to express the new socialist ideal, with its tropes, imageries, and cultural habits, is burdened by history, tainted, 
so to speak, by the very past it vows to cast off. With language functioning as an impediment to the author's intended meaning, sense is constantly threatened by its own dissolution not in senselessness but in perversion. If we can no longer uphold the distinction between form and content in our post-Saussure age, then we have to study the content of form and examine how form can complicate the message of even the most blatantly straightforward revolutionary propaganda. “The New Bride” (新媳婦), Hao Ran's story that features the sleepless young wife on a moonlit late summer night, presents an illuminating case in point.

\section{Chujia 出嫁 and Chujia 出家}

Included in Hao Ran's first story collection, Magpies on the Branch (喜鵲登枝), published in 1958, "The New Bride" was singled out for praise by two notable contemporary critics, Ye Shengtao 葉聖陶 (1894-1988) and Ba Ren 巴人 (i.e., Wang Renshu 王任叔, 1901-1972). ${ }^{14}$ The story is set in a village in the Bohai Bay region that encompasses a large part of Hebei Province. A young woman, Bian Huirong, causes a disturbance in the sleepy village on her wedding night by refusing to conform to the old practice of "roughhousing in the nuptial chamber" (nao dongfang 鬧洞房). Her unconventionality does not stop there: the day after her wedding, she begins working in the fields, and the task she tackles-breaking up manure for use as fertilizer-is none too delicate and not exactly the sort of work considered appropriate for a new bride. Later, when it turns out that female laborers, despite handling an equal amount of work, are granted fewer work credits than the male laborers, Huirong is the one who protests to the head of the production team and 
ultimately sets things right. She is much admired by the young people in the village and endorsed by the director of the agricultural co-op, but predictably comes into conflict with the elders of her family, especially her conservative father-in-law, Liang the Elder. The conflict culminates in a public confrontation when she angrily denounces a young "middle peasant" (zhongnong 中農), Huang Quanbao, for his selfish behavior at a village meeting, and defies her father-in-law who is trying to shut her up and drag her home. After some trials and tribulations, the bride eventually wins the middle peasant over and also becomes reconciled with her father-in-law. The end of the story features a happy family reunion, as the bridegroom, a Youth League cadre working and living away from home at the county headquarters, comes back to the village for a visit after his month-long absence.

The new bride is clearly intended to be a representative of the Socialist New Woman in both body and spirit. In keeping with the stereotypical physical attributes of the "ideal socialist hero," she is strong and muscular, "with a large build and two thick arms, full of strength from head to toe."15 She is public-minded, as demonstrated by her criticism of the selfish middle peasant. Most importantly, she resists traditional gender roles: she does not submit meekly to the roughhousing practice on the wedding night; instead of staying at home and helping her mother-in-law with housework, she decides to go and work at the co-op together with her father-in-law; and she vocally insists on women's rights by demanding "equal work and equal pay." Nevertheless, underneath all the newness of the new bride, there is something old and familiar. We recognize the stereotype of a shrew. There is no shortage of shrew stories from premodern China, either in historical accounts or as literary representation, a fact that has been well demonstrated by Yenna Wu. ${ }^{16}$ One shrew text is especially pertinent because its female protagonist is a problematic 
new bride whose unconventional behavior on her wedding night gets her in much trouble. This is the anonymous vernacular story, "An Account of the Sharp-tongued Li Cuilian" (快嘴 李翠莲记), from the sixteenth-century story collection, Stories from the Qingpingshan Hall (清平山堂話本), compiled by Hong Pian 洪楩.17

In many ways, Li Cuilian the shrew is comparable to Bian Huirong the socialist heroine. Her most prominent feature is her apparent perfection in everything she is and does. Pretty, competent, and hard-working, she seems to be an ideal wife but for one fact: she has a brain, she has a temper, and, worst of all, she is a talker. She has something to say on just about everything, and she always speaks in verse. Within three days of her wedding, she drives her in-laws completely insane. Her husband is forced to divorce her and send her back to her native home. Since her own family blames her bitterly for what has happened, Li Cuilian makes a decision: "Not tolerated by either my husband's family or my own, I will just cut off my hair and become a nun!" She even declines her brother and sisterin-law's offer to accompany her to the convent of her choice, saying: "Once I leave my secular home, every place is my home—not just Clear Voice Temple."18 A story of chujia 出 嫁 ("getting married”) ends with chujia 出家 (“leaving home," which is to say, entering a religious order), as Li renounces all family relationships and the social constraints imposed on her through such relationships.

Like Li Cuilian, Bian Huirong is portrayed as a near-perfect young woman: she is pretty according to the 1950s socialist standard, competent, and hard-working. In her mother-in-law's words, she would have made "a wonderfully lovable daughter-in-law" if only she had been "more obedient and had had a mild temperament."19 Instead, she talks 
back, she reasons, and her "two pretty eyes" can turn into "sharp knives." 20 The most striking correspondence between the two brides is what transpires on the wedding day. After Li Cuilian swears at the match-maker and roundly scolds the astrologer during the ceremony, the newly married couple is finally seated in their nuptial chamber and the astrologer begins to perform a ritual known as the "scattering of grains around bedcurtains." The verses he chants apparently offend Cuilian's sensibilities, and the new bride promptly jumps up, grabs a rolling-pin, deals the astrologer two blows, and drives him out with a cursing doggerel. At this point the groom is roused to anger, citing tradition to rebuke Cuilian. To this Cuilian speaks another doggerel in reply, threatening to throw him out along with the astrologer.

A remarkably similar incident opens Hao Ran's story: on the wedding night, other brides would keep their heads down and not say a word when the wedding guests begin their roughhousing, but Bian Huirong jumps off her kang bed as soon as the male guests crowd into her room, cheerily greeting everybody with a smile:

"Please, everyone, come in quickly. Are you all here to congratulate us on our marriage? Wonderful! We are all fellow members of the same co-op now. We will live together and work together. I am a newcomer and I don't know anything. From now on, I hope you will all watch out for me and help me. Please have a seat, please do!"21

The articulate new bride, devoid of any maidenly reserve and bashfulness, puts all the men to embarrassment. After she has a fiery exchange with Huang Quanbao, the most unruly of the male guests, everybody beats a fast retreat. It is not the groom but the groom's father who complains, and a female neighbor and kin, Auntie Liang, tries to gently rebuke the new 
bride by citing tradition: "Rough-housing in the nuptial chamber is an old custom of many, many years." The bride retorts, "Not all old customs are still useful."22

Nevertheless, Bian Huirong does not represent a simple socialist repackaging of the premodern problem girl, for the differences between the two heroines are equally salient. The modern bride is, on one hand, keenly aware of the importance of female empowerment, and, on the other hand, much more family-oriented than her premodern counterpart. While Li Cuilian discovers "freedom and ease" (zizai 自在) in a Buddhist convent, for the socialist new woman, "leaving home" is out of the question, not just because entering a religious order is no longer a viable solution in a socialist society, but because of the changed context of "home." 23

\section{A Family Woman}

Like many heroes and heroines of Cultural Revolution novels and short stories, Bian Huirong is an orphan, whose parents, as is typical of the genre, have died a martyr's death for the revolution..$^{24}$ She has grown up with her brother and sister-in-law, who notably are both party members. Thus, the Party is her symbolic parents. After she gets married, she finds herself a member of two new families: the larger family of the agricultural co-op, and a smaller family constituted primarily of her parents-in-law. Her husband who works and lives away from her is only marginally in the picture.

The traditional family hierarchy of a patriarchal society, with the senior male reigning as the head of the family, never falters in this fictional universe. A striking conversation between father and son about the future of the bride takes place in the middle of the story. Liang Senior [you refer to him as Liang the Elder earlier-please use one 
or the other throughout], who is upset with his progressive daughter-in-law, tells his son He'nan: "When you go back to work, take your wife with you. Out of sight, out of mind." To this the son replies, "Let her stay home with you for a month. After a month I will be back for a vacation. By that time, as long as you can bear to part with her, I will take her away to live outside." 25 The discussion in no way involves Bian Huirong herself. She is a passive object being negotiated and decided upon between the men in the family. A similar conversation is repeated at the end of the story, but with a twist. While the new bride is cooking family dinner with her mother-in-law in the kitchen, the son informs the father that he plans to take his wife with him. The father, who has changed his attitude toward Bian Huirong by now, protests:

“It isn't easy for a young couple to make a life together outside. How can we elders set our mind at ease about this? You are not all that far away; why cannot you just come home and visit her when you have a chance?"

He'nan said, "Well, it's really not a problem for us; it's just for you and Ma who are getting on there...."

Liang the Elder glanced at his son, not quite able to put his finger on his feelings. He said in a soft voice, "Me and your Ma, well, since you are so often away, how can we manage without someone like her by our side?"26

This is the end of the story, and Liang Senior literally has the last word. For all her sturdy physique and independent spirit, the new bride is a pawn, loved and fought over by father and son. She herself is complicit in the male game of power. The day after her wedding, her mother-in-law tries to give her guidance in dealing with household matters; the bride replies, much to her mother-in-law's chagrin: “After He'nan is gone, Dad and I will go and 
join in the work at the co-op. You can stay at home and take care of these things." 27 Though standing up for her own liberation from the old way of life, she is clearly not troubled by the structure of gendered division of labor per se, with women doing housework inside and men working outside; the only difference is that she as a young woman wants to join the men and leave the older woman to do the housework.

Older women are represented by two familiar types in this story: the noisy and bossy type embodied by Auntie Liang, and the nice, quiet, and submissive type like Mother Liang. They are basically treated as backward and inconsequential. While being an older male earns one a position of authority, either in public or in private, being an older female signifies an almost total loss of value in family and society. Though also women, Mother Liang and Auntie Liang are clearly not in the same league as Bian Huirong or Cuiying, the young female vice-head of the production team. Indeed, both Mother Liang and Auntie Liang are referred to only by their status earned through marriage while the younger female characters are the ones being allowed the dignity and individuality of having a personal name. A dialogue in the story indicates that naming is a conscious authorial choice: when Cuiying addresses the bride as "Big Sister-in-law," the bride immediately puts a stop to it, saying, "Don't call me that. My name is Bian Huirong." "Oh I see," Cuiying says, "Comrade Bian Huirong!" ${ }^{28}$ Having a name, as opposed to being known in kinship terms, signifies having an identity and a position in society. Gender equality is, however, complicated by age.

Whether in her immediate family or in the larger family of the agricultural co-op, the structure of male authority never changes. The director of the co-op and the head of the production team are both male, and Liang the Elder is the head of a sub-division of the 
production team. Only when he is sick does the bride get to stand in for him for a day. On the outside, the bride constantly appeals to the authority of the co-op director in all of her difficult situations; on the inside, she desperately seeks her father-in-law's approval. In fact, when we look closely, we are not so sure that the bride has ever broken through to the real outside. Her husband, He'nan, works as a cadre in the Communist Youth League at the county level; he and his father both refer to the county seat as “outside" (外邊). Despite being active outside her immediate household and the traditional "inner quarters," Bian Huirong has never been on the real "outside." She is relegated to a perpetual nei 內, "inside," and hierarchical layers are mapped on gendered spatial division and on local space.

At the end of the day, the bride is just a meek daughter-in-law and an acquiescent wife. The family reunion at the end is more about her reconciliation with her father-in-law than about her brief reunion with her husband. The socialist new woman is much more politically correct than the sixteenth-century heroine when measured by a neo-Confucian standard, which has been the dominant moral standard in society since late imperial times. The latter subverts the family and social order by opting out of it altogether.

\section{The Subtext of Incest and Adultery}

Bian Huirong's filial piety nevertheless finds expression in strange ways. Section Four of the story opens with the following passages:

It was a late summer night, cool, quiet. The moon that was sinking in the western sky gilded the leaves of the white pear tree on the east side. The half-ripe pears hanging on the branches were as shiny and beautiful as if carved out in dark 
green jade. The cassia tree blossoming outside of her window eagerly sent forth a sweet scent.

Bian Huirong softly opened the half-closed door of her room and went to bed without bothering to turn on the lamp. Her heart felt as if it were filled with a pile of jumbled iron wires: frustrated, and aching. With what happened today, she tasted misery for the first time in her life. ${ }^{29}$

This is the scene that I describe at the beginning of this chapter. The young bride sleepless in bed is dwelling on her earlier confrontation with her father-in-law with pain and regret. The narrative language setting up the atmosphere that frames such admirable sentiments is unmistakably lyrical and romantic: the moon, the tree bearing fruits, and the aromatic cassia blossoms are all hackneyed poetic images that can evoke sensibilities far more fitting for lovers. Pear (li 梨) puns with “separation” ( $l i$ 離), and seems particularly relatable to Bian Huirong's situation, whose husband has left for his job in the county seat just a few days after their wedding. The most remarkable image is that of the "jumbled iron wires," luan tiesi 亂鐵絲 (literally, “tangled iron threads”), filling the bride’s heart. Si 絲 ("silk" or "silk threads") is commonly used as a pun for si 思 ("longing") in traditional love songs, and "tangled silk threads" (luansi 亂絲) is the famous metaphor in the song lyric attributed to the lyricist Li Yu 李显 (937-978) to the tune title “The Pleasure of Meeting":

Without a word I climbed the western tower, the moon was like a hook.

The silent yard stretched deep through chestnut trees, 
enclosing autumn, cool and clear.

You can cut it, but never cut it through,

Get it set,

then it's a mess again-

that's the sadness of being apart.

It has a flavor all its own

in the human heart. ${ }^{30}$

無言獨上西樓, 月如鉤, 寂寞梧桐深院鎖清秋。

剪不斷, 理還亂, 是離愁。別有一番滋味在心頭。

One need not wonder about Han Ran's level of classical learning, since the lines, "You can cut it, but never cut it through, / Get it set, then it's a mess again," have practically acquired the status of a proverb in the Chinese language, and Hao Ran had been a passionate reader of China's classical novels as well as an avid traditional opera fan..$^{31}$ The punchline is wellknown: the very thing that resists cutting and severing is ironically the "sadness of being apart," figured here as tangled threads/longing. By transforming "silk threads" into "iron threads," Hao Ran gives an age-old image a modern twist.

What we have here are two discourses that are uncomfortably juxtaposed with each other. The "tangled iron threads" in Bian Huirong's heart, like her intense thoughts about her father-in-law on a beautiful summer night, are as discordant to the romantic, sensuous setting as the moon, the cassia, and the pears are to a story with a socialist message. Hao Ran is trying to write a simple story of binary opposition: progressiveness versus conservatism, public-mindedness versus selfishness; but the story is problematized by the 
nuances of a literary language out of his control. The built-in cultural meaning of the images he employs brings a troubling dimension of repressed sexuality to the fore.

As the story moves on, the story's title, "Xin xifu," takes on an unexpected sense of ambiguity. Xifu, a northern Chinese colloquial expression for wife, is also the term indicating daughter-in-law. Obviously Bian Huirong is both, but she seems much more invested in the latter role. Indeed, she so successfully repairs her relation with her fatherin-law that he no longer wants to part with her. At the end of the story, when the son suggests taking Bian Huirong to the county seat to live with him, Liang Senior is "not quite able to put his fingers on his feelings" (心里不知啥味, or literally, “not knowing the flavor in his heart"). On the one hand, this phrase echoes a sentence that describes how the newlywed couple feels upon seeing each other after their month-long separation: "They both had this feeling in their hearts that they could not quite articulate” (心里都有一股说不 出来的滋味); 32 on the other hand, it evokes the last line of Li Yu's song lyric: “It has a flavor all its own in the human heart" (別有一番滋味在心頭). The "sadness of being apart," never articulated between the separated young couple, is displaced to a doting father-in-law. Whether these textual echoes are deliberate is beside the point. Rather, what deserves note are the negative terms adopted by the author—not knowing (buzhi 不知), and unable to articulate (shuobuchulai 说不出来): besides slyly constituting the narrator's comments on the limits of conscious knowledge and language, the negations simultaneously broach and suppress illicit desire (it is important to note that not only incestuous passion is forbidden, but romantic love between husband and wife is likewise inappropriate in the revolutionary 
discourse). Ultimately, a linguistic approximation to incest forms part of the reading pleasure, and the verbal furtiveness replicates the very form of the taboo romance itself.

The absence of the bridegroom through most of the story is underscored by the young wife's intense interaction not only with her father-in-law but also with the other backward male character, Huang Quanbao, who clashes with her on her wedding night. Just like Liang Senior, Huang Quanbao becomes incapacitated in the course of the story largely thanks to his conflict with Bian Huirong. Each instance of incapacitation is designed as an act of poetic justice, with the backward males punished and the progressive bride empowered, for she is put in the position of taking care of the disabled males. In each case, however, Bian Huirong is placed in close physical proximity to the men in a compromising manner. When her father-in-law is sick, she rushes into his room in the middle of the night to feel his forehead before she has a chance to button up her blouse. When Huang Quanbao pierces his foot on a broken willow branch in the field, she places his bleeding foot in her lap, tears off a large part of her blouse, and bandages his foot with it, as "blood saturated her pants and sullied both of her hands." ${ }^{\prime 33}$ It is perhaps inevitable that blood should flow in a story about a bride, but the blood that might have been appropriate for the wedding night is displaced to a public setting tinted with socialist pastoralism and charged with erotic tension.

The demasculinization of the two backward male characters is completed by their tears of gratitude and repentance, as they are moved by Bian Huirong's selflessness and magnanimity. A great deal of bodily fluid—sweat, tears, and blood-flows in the story, although none comes from the bride herself, who is portrayed as a superwoman. After walking five or six miles to get a doctor for her father-in-law in the middle of the night, she 
works in the field all day, and at the end of the day carries the immobilized Huang Quanbao on her back all the way home. Hers is a body devoid of weakness or desire, the idealized body of a "new" member of the new society.

When the story was reprinted in a 1973 selection of Hao Ran's stories, Songs of Spring (春歌集), Hao Ran revised it heavily. Many of the revisions try to repress, but instead only serve to highlight, the sexual tension and gender stereotyping in the original story. In depicting the custom of "roughhousing in the nuptial chamber," the original version states that sometimes wedding guests would even "rip off the new bride's clothes, or spray pepper powder in her nostrils." ${ }^{34}$ In the revised version the guests are said to "spray pepper powder in the new bride's nostrils, or pour cold water over the new bride's head." 35 The sexual violence inherent in the phrase, bo yifu 剝衣服 (rip off clothes), as opposed to the more neutral tuo yifu 脫衣服 (take off clothes), and the speculative nakedness of this bride, Bian Huirong, are edited out, although they resurface in the bride's voluntary stripping of her blouse to dress the wound of Huang Quanbao's foot.

Many more revisions occur in the "foot cutting" episode. The original version of the episode contains the following words: "Women are often afraid of blood. Several women here were all stunned: some covered their eyes, and some were so scared that they ran away." 36 The revised version merely states: "Several women were all stunned by the blood and did not know what to do." ${ }^{37}$ The simplicity of the statement accentuates Bian Huirong's courage and resourcefulness without disparaging the other women or generalizing about the perceived female weakness in general. Finally, the description "blood stained her pants and sullied both of her hands" is revised to read "blood flew onto Bian Huirong's pants and made a large red blot." The avoidance of the mention of hands seems to be an attempt to 
downplay the physicality of Bian Huirong's tending of Huang Quanbao. Earlier, as they work side by side in the field, she is said to be "chatting and laughing with him like nothing had happened [between them];" the revised version deletes "with him."38 The deletion, another attempt to distance Bian Huirong from Huang Quanbao, tones down a classic example of "unresolved sexual tension" between a male and female character. The makeover, effected by Hao Ran during the Cultural Revolution era, of his early short stories published between 1958 and 1960 is a conscious act of suppression that exposes rather than conceals. ${ }^{39}$

\section{Coda}

Earlier scholars have noted Hao Ran's recycling of techniques and motifs from traditional Chinese drama and fiction. ${ }^{40}$ Michael Egan even goes so far as to argue that a sense of cultural and literary familiarity about Hao Ran's fiction is what makes Bright Sunny Skies successful as opposed to his later work The Golden Road, which he sees as impoverished because it is largely deprived of "references to traditional culture." 41 In this chapter, I have attempted to take the argument into a different direction by stressing how the socialist content of Hao Ran's fiction is infinitely complicated by the literary tropes and images he uses. On a surface level, [it seems odd to speak of a process of sublimation as "conscious," quite apart from the fact that the agent appears to be revolution itself] revolution sublimates and normalizes every wayward impulse; on an underlying level, however, every wayward impulse continues to seek gratification without ever bothering to justify itself because it is always already disguised under the normalizing discourse of the revolution. There is a gray area where these two levels of reading negotiate with each other 
and produce a special form of covert pleasure. At least one reader talks about having had sexual fantasies about the new bride during his sent-down years in the countryside, though he complains that Hao Ran's writing was "too clean" for him to use the story as an actual aid for masturbation. ${ }^{42}$

The Cultural Revolution movement represents a mass quest for transparency, which, in a totalitarian regime, makes control possible and easy. People were classified and labeled as "Black Five Categories" or "Red Five Categories," and their identities were marked out by physical signs during struggle sessions, such as dunce caps, plaques hung around the neck with one's name and class identity written on it, or the more permanent "yin yang haircut" (a haircut that shaves half of the head). On a deeper level, transparency was sought through “exposure” (jiefa 揭发, jielu 揭露, or baolu 暴露), whether it be the uncovering of a "hidden class enemy" or a public self-examination and self-critique. When Hao Ran revised his early stories during the Cultural Revolution era, he was aiming to make the stories more straightforward and transparent as revolutionary propaganda. As he put it, he felt that his literary language in those early stories "lacked precision, was interspersed with many obscure dialect words and slang, and even contained some naturalistic elements that hurt the images of the characters." ${ }^{43}$ He revised and excised, only to highlight what he desired to suppress.

The more serious impediment to Hao Ran's attempt to simplify his stories is the fact that, by its very nature, language resists the obsessive quest for transparency. Even in a story as straightforward as "The New Bride," the opacity of language resists the writer's attempt to sing a simple ode to the socialist new woman. In the Greek myth about Oedipus and the Sphinx, the lack of transparency in language drives people to despair and death and 
creates a horror; Oedipus brought back transparency by solving the Sphinx' riddle, which destroyed the horror embodied in the Sphinx. Agamben argues that the Sphinx was not asking people to solve a riddle but was merely proposing a mode of speech. Oedipus' sin was therefore not incest, but to destroy that mode of speech and inaugurate a breach between signifier and signified. ${ }^{44}$ In this regard, Hao Ran's real achievement as a writer lies in his reestablishment, perhaps completely contrary to his intention, of a mode of speech wrought with ambiguity and double meanings. The sublimation of an incestuous impulse by resorting to a progressive socialist discourse both eliminates the need for committing the act of incest and paradoxically gives room for the impulse to continue to exist. It is a cultural revolution that "always must be carried on, / And still be doing, never done." 


\section{WORKS CITED}

Agamben, Giorgio. Stanzas: Word and Phantasm in Western Culture. Trans. Ronald L. Martinez. Minneapolis, MN: University of Minnesota Press, 1993.

Ba Ren 巴人. “Lüe tan Xique dengzhi ji qita”略談喜鵲登枝及其他 [Brief discussion of Magpies on a Branch and other topics] Renmin wenxue 人民文學 [People's literature] 11 (1959)::115-120.

Birch, Cyril. "Continuity and Change in Chinese Fiction." Modern Chinese Literature in the May Fourth Era. Ed. Merle Goldman. Cambridge, MA: Harvard University Press, 1977. $385-404$.

Chang, H. C. Chinese Literature: Popular Fiction and Drama. Edinburgh, UK: Edinburgh University Press, 1973.

Clark, Paul. The Chinese Cultural Revolution: A History. Cambridge, UK: Cambridge University Press, 2008.

Egan, Michael. “A Notable Sermon: The Subtext of Hao Ran's Fiction.” Popular Chinese Literature and Performing Arts in the People's Republic of China: 1949-1979. Ed. Bonnie McDougal. Berkeley, CA: University of California Press, 1984. 224-243. Guo Moruo 郭沫若 and Zhou Yang 周揚, ed. Hongqi geyao 紅旗歌謠 [Red flag ballads]. Beijing: Hongqi zazhishe, 1958.

Hao Ran 浩然.Chun ge ji 春歌集 [Songs of spring]. Tianjin: Tianjin renmin chubanshe, 1973.

---. “Chunge ji bianxuan suoyi” 春歌集編選瑣憶 [Miscellaneous memories of the selection and compilation of Songs of Spring]. Hao Ran yanjiu zhuanji 浩然研究專集 [Special 
collection of Hao Ran studies]. Ed. Sun Dayou 孫達祐 and Liang Chunshui 梁春水. Tianjin: Baihua wenyi chubanshe, 1994. 93-111.

---. Hao Ran koushu zizhuan 浩然口述自傳 [Hao Ran's oral autobiography]. Comp. Zheng Shi 鄭實. Tianjin: Tianjin renmin chubanshe, 2008.

---. Xique dengzhi 喜鵲登枝 [Magpies on a branch]. Beijing: Zuojia chubanshe, 1958.

Hong Pian 洪楩, comp., Qingpingshan tang huaben 清平山堂話本 [Stories of the Qingpingshan Hall]. Anno. Tan Zhengbi 譚正璧. Shanghai: Gudian wenxue chubanshe, 1957.

King, Richard. Milestones on a Golden Road: Writing for Chinese Socialism, 1945-80. Vancouver, Canada: UBC Press, 2013.

Liu Xueyan 劉學顏. Ai wu zhu 愛無助 [Love is helpless]. Nanchang, Jiangxi: Baihuazhou wenyi chubanshe, 2011.

Mao Zedong. Nineteen Poems. Beijing: Foreign Language Press, 1958.

--. "Talks at the Yan'an Forum on Literature and Art," trans. Bonnie McDougal. Reading in Modern Chinese Literary Thought. Ed. Kirk Denton. Stanford, CA: Stanford University Press, 1996. 458-484.

Miller, J. Hillis. Illustration. Cambridge, MA: Harvard University Press, 1992.

Mitter, Rana. A Bitter Revolution: China's Struggle with the Modern World. Oxford, UK: Oxford University Press, 2004.

Mittler, Barbara. A Continuous Revolution: Making Sense of Cultural Revolution Culture. Cambridge, MA: Harvard University Asia Center, 2012. 
Owen, Stephen, ed. and trans., An Anthology of Chinese Literature: Beginnings to 1911. New York: W. W. Norton, 1996.

Pollard, D. E. "The Short Story in the Cultural Revolution." China Quarterly 73 (1978): 99121.

Tian Ying 天鷹. Yijiuwuba nian Zhongguo min'ge yundong 1958 年中國民歌運動 [China's Folk Song Movement of 1958]. Shanghai: Shanghai wenyi chubanshe, 1959, $1978 \mathrm{rpt}$.

Wu, Yenna. The Chinese Virago: A Literary Theme. Cambridge, MA: Harvard Asia Center, 1995.

Yang, Lan. "The Ideal Socialist Hero: Literary Conventions in Cultural Revolution Novels." China's Great Proletarian Cultural Revolution: Master Narratives and Post-Mao Counternarratives. Ed. Woei Lien Chong. Lanham, MD: Rowman and Littlefield, 2002. 185-211.

Ye Shengtao 葉聖陶. “Xin nongcun de xin miaomao: Du Xique dengzhi” 新農村的新面貌: 讀 喜鵲登枝 [The new face of the new countryside: upon reading Magpies on a Branch]. Dushu 讀書 [Reading] 14 (1958): 23-24. 
Notes:

${ }^{1}$ Hao Ran, Xique deng zhi 喜鵲登枝 [Magpies on a Branch] (Beijing: Zuojia chubanshe, 1958), 21 and 16.

${ }^{2}$ Hao Ran, “Chunge ji bianxuan suoyi” 春歌集編選瑣憶 [Miscellaneous memories of the selection and compilation of Songs of Spring], in Hao Ran yanjiu zhuanji 浩然研究專集

[Special collection of Hao Ran studies], ed. Sun Dayou 孫達祐 and Liang Chunshui 梁春水

(Tianjin: Baihua wenyi chubanshe, 1994), 100.

${ }^{3}$ Hao Ran, “Miscellaneous memories,” 110.

4 Paul Clark, The Chinese Cultural Revolution: A History (Cambridge, UK: Cambridge University Press), 5.

${ }^{5}$ See Rana Mitter, A Bitter Revolution: China's Struggle with the Modern World (Oxford, UK:

Oxford University Press, 2004), 230; also Barbara Mittler, A Continuous Revolution: Making Sense of Cultural Revolution Culture (Cambridge, MA: Harvard University Asia Center, 2012), 30-31.

${ }^{6}$ See Mao, "Talks at the Yan'an Forum on Literature and Art," trans. Bonnie McDougal, in Reading in Modern Chinese Literary Thought, ed. Kirk Denton (Stanford, CA: Stanford University Press, 1996): 458-484.

7 Tian Ying 天鷹, Yijiuwuba nian Zhongguo min'ge yundong 1958 年中國民歌運動 [China's Folk Song Movement of 1958] (Shanghai: Shanghai wenyi chubanshe, 1959; 1978 rpt), 3031 and 51.

${ }^{8}$ Hongqi geyao 紅旗歌謠 [Red flag ballads], ed. Guo Moruo 郭沫若 and Zhou Yang 周揚 (Beijing: Hongqi zazhishe, 1958), 2. 
${ }^{9}$ Red Flag Ballads, 3.

${ }^{10}$ Hao Ran, Hao Ran koushu zizhuan 浩然口述自傳 [Oral autobiography by Hao Ran], comp. Zheng Shi 鄭實 (Tianjin: Tianjin renmin chubanshe, 2008), 111-160.

${ }^{11}$ Hao Ran, Oral Autobiography, 303-304. See also Richard King, Milestones on a Golden Road: Writing for Chinese Socialism, 1945-80 (Vancouver, Canada: UBC Press, 2013), 114115.

12 J. Hillis Miller, Illustration (Cambridge, MA: Harvard University Press, 1992), 55. 13 Mittler, A Continuous Revolution, 16.

14 Ye Shengtao 葉聖陶, “Xin nongcun de xin miaomao: Du Xique dengzhi” 新農村的新面貌: 讀喜鵲登枝 [The new face of the new countryside: upon reading Magpies on a Branch], Dushu 讀書 [Reading] 14 (1958): 23. Ba Ren 巴人, “Lue tan Xique dengzhi ji qita”略談喜鵲 登枝及其他 [A brief discussion of Magpies on a Branch and others]. Renmin wenxue 人民文 學 [People’s literature] 11 (1959): 117.

15 Lan Yang, “The Ideal Socialist Hero: Literary Conventions in Cultural Revolution Novels,” in China's Great Proletarian Cultural Revolution: Master Narratives and Post-Mao

Counternarratives, ed. Woei Lien Chong (Lanham, MD: Rowman and Littlefield, 2002), 192193. Hao Ran, Magpies on a Branch, 5.

16 Yenna Wu, The Chinese Virago: A Literary Theme (Cambridge, MA: Harvard University Asia Center, 1995).

17 The story is rendered simply as "The Shrew” in H. C. Chang's English translation. H.C. Chang, Chinese Literature: Popular Fiction and Drama (Edinburgh, UK: Edinburgh University Press, 1973), 32-55. 
${ }^{18}$ Hong Pian 洪梗, comp., Qingpingshan tang huaben 清平山堂話本 [Stories of the Qingpingshan Hall], annot., Tan Zhengbi 譚正璧 (Shanghai: Gudian wenxue chubanshe, 1957), 66.

${ }^{19}$ Hao Ran, Magpies on a Branch, 5.

${ }^{20}$ Hao Ran, Magpies on a Branch, 14.

${ }^{21}$ Hao Ran, Magpies on a Branch, 2-3.

${ }^{22}$ Hao Ran, Magpies on a Branch, 4.

${ }^{23}$ Hong Pian, Stories of the Qingpingshan Hall, 66.

${ }^{24}$ Yang, "The Ideal Socialist Hero," 191. See also Pollard, "The Short Story in the Cultural Revolution," 104.

${ }^{25}$ Hao Ran, Magpies on a Branch, 11.

${ }^{26}$ Hao Ran, Magpies on a Branch, 21.

27 Hao Ran, Magpies on a Branch, 6.

${ }^{28}$ Hao Ran, Magpies on a Branch, 7.

${ }^{29}$ Hao Ran, Magpies on a Branch, 15-16.

${ }^{30}$ Translated by Stephen Owen, in An Anthology of Chinese Literature: Beginnings to 1911 (New York: W. W. Norton, 1996), 569.

${ }^{31}$ By his own account, Hao Ran's first literary education consists of oral story-telling tradition, live theatre performance, classical vernacular novels and, among other things, chantefables and opera play scripts. Hao Ran, Oral Autobiography, 25-26, 47-57.

${ }^{32}$ Hao Ran, Magpies on a Branch, 20.

${ }^{33}$ Hao Ran, Magpies on a Branch, 18. 
34 Hao Ran, Magpies on a Branch, 2.

${ }^{35}$ Hao Ran, Chun ge ji 春歌集 [Songs of spring] (Tianjin: Tianjin renmin chubanshe, 1973),

23.

${ }^{36}$ Hao Ran, Magpies on a Branch, 18.

${ }^{37}$ Hao Ran, Songs of Spring, 38.

${ }^{38}$ Hao Ran, Magpies on a Branch, 17. Hao Ran, Songs of Spring, 37.

${ }^{39}$ For an extensive discussion of the politics of Hao Ran's revision of his early short stories, see Xiaofei Tian, "Castration for the People: The Politics of Revision and the Structure of Violence in Hao Ran's Short Stories," in The Making and Remaking of China's "Red Classics": Politics, Aesthetics and Mass Culture in Literary Icons of Socialism and Their Contemporary Remakes, ed. Li Li Peters and Rosie Robert, work in progress. [Please add to your

\section{bibliography]}

40 See Cyril Birch, “Continuity and Change in Chinese Fiction," in Modern Chinese Literature in the May Fourth Era, ed. Merle Goldman (Cambridge, MA: Harvard University Press, 1977), 397-400. See also Michael Egan, “A Notable Sermon: The Subtext of Hao Ran’s Fiction,” in Popular Chinese Literature and Performing Arts in the People's Republic of China: 1949-1979, ed. Bonnie McDougal (Berkeley, CA: University of California Press, 1984), 227-231.

${ }^{41}$ Egan, “A Notable Sermon,” 233.

${ }^{42}$ Liu Xueyan 劉學顔. $A i w u$ zhu 愛無助 [Love is helpless] (Nanchang, Jiangxi: Baihuazhou wenyi chubanshe, 2011), 153.

${ }^{43}$ Hao Ran, “Miscellaneous memories," 107. 
${ }^{44}$ Giorgio Agamben, Stanzas: Word and Phantasm in Western Culture, trans. Ronald L. Martinez (Minneapolis, MN: University of Minnesota Press, 1993), 135-139. 